\title{
Manitoba's forest policy regime: Incremental change, concepts, actors and relationships
}

\author{
by Jodi Griffith ${ }^{1}$, Alan P. Diduck ${ }^{2, *}$ and Jacques Tardif ${ }^{3}$
}

\begin{abstract}
In response to the emergence of Sustainable Forest Management (SFM), forest operations, policies, and governance have become more inclusive of multiple values and of the people holding these values. To assess the extent to which these types of changes have occurred in Manitoba, government legislation and policy documents were examined and semi-directed interviews were conducted with 29 key actors in Manitoba's forest policy regime. In Manitoba, objectives, principles and concepts relating to sustainability and ecosystem-based management have been incorporated into forest policies but not in forest legislation. Additionally, public involvement opportunities have expanded and more people are now involved in advisory capacities. However, a closed policy network and institutional stability have meant that the provincial government and the forest industry maintain primary policy- and decision-making responsibility in Manitoba's forest policy regime. As a result, parties who would need to be included for SFM ideals to be realized are excluded from the network. For SFM to take a deeper hold in Manitoba in both policy and in management practices, transformative change needs to occur. A broader array of interests needs a voice at the center of the network, and The Forest Act requires amendment to entrench SFM principles and core concepts.
\end{abstract}

Keywords: forest governance, Sustainable Forest Management, sustained yield, policy regime, Manitoba, public involvement, Aboriginal participation

\section{RÉSUMÉ}

En réaction à l'apparition de l’aménagement forestier durable (AFD), les opérations forestières, les politiques et la gouvernance tiennent maintenant davantage compte de multiples valeurs et des gens à qui elles tiennent à cour. Pour évaluer dans quelle mesure ces types de changements sont survenus au Manitoba, nous avons passé en revue la législation gouvernementale et les documents politiques et conduit des entrevues semi-dirigées auprès de 29 acteurs-clefs de la politique forestière manitobaine. Dans cette province, les objectifs, les principes et les concepts de la durabilité et de l'aménagement écosystémique des forêts se retrouvent maintenant dans les politiques forestières, mais pas dans la législation forestière. De plus, le public a maintenant plus doccasions de participer aux consultations et effectivement de plus en plus de personnes s'impliquent dans les mécanismes consultatifs. Toutefois, en raison d'un réseau politique fermé et de la stabilité des institutions, cest encore le gouvernement provincial et l'industrie forestière qui prennent lessentiel des décisions en matière de politiques et de législations dans le régime forestier du Manitoba. En conséquence, les parties qui devraient être impliquées afin d’atteindre les idéaux de l'AFD se trouvent encore exclues. Si l'on souhaite implanter davantage l'AFD au Manitoba, il reste d'importants changements à faire tant au niveau des politiques que dans laménagement. Il faudra en outre qu'un plus grand nombre d'intervenants ait voix au chapitre et la Loi sur les forêts doit être modifiée afin d'y inclure les principes de l'AFD et ses concepts fondamentaux.

Mots clés : gouvernance forestière, aménagement forestier durable, rendement durable, régime forestier, Manitoba, participation du public, participation des Autochtones

\footnotetext{
${ }^{1}$ Department of Environment and Geography, University of Manitoba, Winnipeg, Manitoba R3T 2N2. Jodi Griffith is currently affiliated with the Centre for Forest Interdisciplinary Research, The University of Winnipeg, 515 Portage Avenue, Winnipeg, Manitoba R3B 2E9. ${ }^{2}$ Centre for Forest Interdisciplinary Research, Department of Environmental Studies and Sciences, The University of Winnipeg, Winnipeg, Manitoba R3B 2E9.

${ }^{3}$ Centre for Forest Interdisciplinary Research, Departments of Biology and Environmental Studies and Sciences, The University of Winnipeg, Winnipeg, Manitoba R3B 2E9.

*Corresponding author. E-mail: a.diduck@uwinnipeg.ca
} 


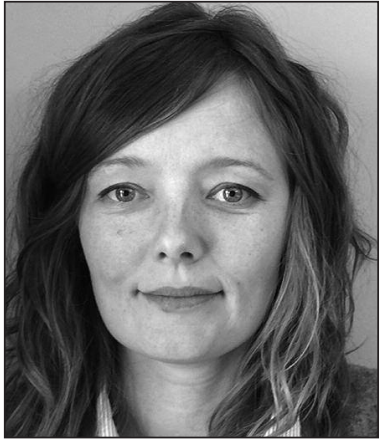

Jodi Griffith

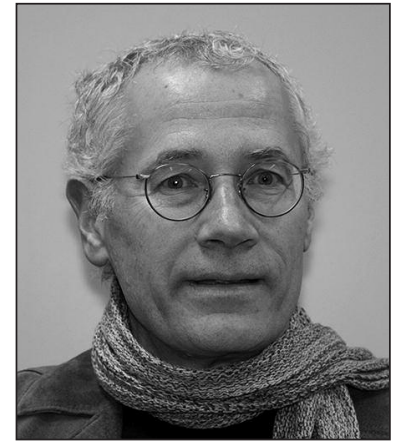

Alan P. Diduck

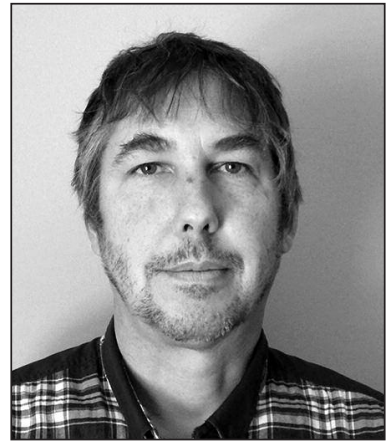

Jacques Tardif sites, cottage lots and hunting opportunities, and conducting broad-area planning in collaboration with First Nations, e.g., Wabanong Nakaygum Okimawin (Manitoba Conservation and Water Stewardship 2013b).

Given the wide-ranging significance of forests in Manitoba, the advent of Sustainable Forest Management (SFM) was an important development in the evolution of forest policy in the province. Emerg-

\section{Introduction}

Manitoba is referred to as a "prairie province", yet nearly one half of the province's total land area consists of forests (Manitoba Conservation 2001). The province ranks fifth in Canada in terms of total forest area (26.3 million ha) and merchantable volume of timber (Manitoba Conservation 2001). Like many Canadian provinces, Manitoba's economy and culture are influenced and shaped by the boreal forest and the forest sector. In 2012, the forest sector generated 5100 direct jobs and realized revenue of a little more than $\$ 741$ million from total manufactured forest goods. The wood and paper products manufacturing industries each generated about 47 $\%$ of this revenue, while the logging industry generated the remaining $6 \%$ (Natural Resources Canada 2013a).

Economic opportunities associated with forestry and other resource sectors have recently been explored for the potential benefits they can provide for Aboriginal communities (Manitoba Conservation and Water Stewardship 2013a). This is a growing area of interest in Manitoba where nearly $50 \%$ of the Aboriginal population (87 265 people) live in the Parklands, North, and Southeast economic regions, which are important forested areas of the province (Manitoba Aboriginal and Northern Affairs 2012, Manitoba Jobs and the Economy 2014).

In recent years, the provincial government has acknowledged a need to increase collaborative efforts with Aboriginal communities (Manitoba Conservation and Water Stewardship 2013a). Non-timber forest products, special timber allocations, and co-management are opportunities that have been explored (Manitoba Conservation 2006). Despite these efforts, Aboriginal people remain under-represented in Manitoba's forest economy (Manitoba Conservation 2006), and collaborative initiatives involving Aboriginal people, the provincial government, and the forest industry are not highly advanced (Fortier et al. 2013). Further, Aboriginal people have median incomes far below that of the Manitoba population as a whole (Manitoba Aboriginal and Northern Affairs 2012).

In addition to economic benefits, forests provide Manitobans with various ecological, cultural, spiritual and recreational advantages. In recent years, several initiatives have been launched to protect and enhance such benefits. Examples include protecting ecologically and culturally important wildlife species (e.g., Pine Marten and Boreal Woodland Caribou), addressing a continually increasing demand for camp- ing from the Brundtland Commission's articulation of sustainable development (United Nations 1987), and the "Forest Principles" established at the Rio Summit (United Nations 1992), SFM has become a foundation of forest policy in Canada (Natural Resources Canada 2013b). Sustainable Forest Management has been defined as "the maintenance or enhancement of the ecological, social and economic components of forested areas" (Adamowicz and Burton 2003: 45). It has been viewed as a mechanism for balancing development and environmental interests (Howlett and Rayner 1995) and for addressing diverse interests of multiple societal actors (Wellstead et al. 2002). Additionally, SFM has been conceptualized as a vehicle for enhancing intra and intergenerational equity, including reducing current socioeconomic disparities in society and conserving resources for future generations (Sneddon et al. 2006). Further, enhanced democracy and increased opportunities for meaningful public participation are seen as both an instrument and an outcome of SFM (Hammersely Chambers and Beckley 2003).

Despite its promise, the precise nature of SFM is uncertain, as are effective ways to implement it in practice. These problems are due, in part, to the complexity of the concept (Adamowicz and Burton 2003). Sustainable Forest Management is highly integrative and therefore developing comprehensive frameworks of principles, practices, methods, criteria and indicators has been challenging and remains an enduring concern. As well, it has been acknowledged that the concept is vague and has been used inappropriately to further economic development agendas that have contributed to greater environmental degradation and social inequality (Adamowicz and Burton 2003). Regarding the public participation and social equity aspects of SFM, some observers have argued that new societal actors have yet to become institutionalized in forest policy-making, and forest management continues to be carried out largely by government and industry. Essentially, longstanding actors have maintained a stronghold in forest policy networks in Canada, which has stifled the materialization of the emerging SFM paradigm (Howlett and Rayner 2006). That said, forest policy and management have not been immune to influences from the larger deliberative turn in environmental governance (Dryzek 2002), and new ideas such as community forestry (Bullock and Hanna 2012) and new actors such as Aboriginal peoples (Wyatt et al. 2013) are playing an increasingly important role in Canada's forest sector. 


\section{Purpose and Research Questions}

Given the importance of forests to Manitoba and the uncertain nature of SFM as currently practiced in the province, the aim of this study was to describe the evolution of Manitoba's forest policy regime, particularly in response to the emergence of SFM. We have adopted Howlett's (2001: 6) definition of policy regime, namely sustained political arrangements consisting of: 1) state-societal relations affecting the style or process of sectoral policy-making; 2) ideas related to governing those interactions and influencing policy substance and choice of instruments; and, 3) institutions that regularize the content and style of policy-making in the sector concerned.

Our research questions were: 1) To what extent have new ideas and actors been introduced into the regime? 2) How have forest policy actors' roles changed? 3) What aspects of the regime have undergone the most significant changes? We did not expect to find transformative change, but we anticipated the policy regime to be more inclusive of multiple interests, values, and policy actors, including having a wider array of people involved in decision-making. We also expected to find changes in legislation and in other high-level policy instruments as well as in operational policies.

\section{Methods}

Policy regime analysis was used as a guiding framework. Such analysis examines "the overall tenor and types of interactions existing among institutions, actors and ideas that tend to congeal into relatively long-term, institutionalized patterns of policy and policy-making" (Howlett 2001: 5). Howlett (2001) identified business, government, labour, academics, lawyers, recreationalists, environmentalists and Aboriginal groups as the main forest policy regime actors in Canada. These actors were used as a starting point to identify key actor groups involved in Manitoba's regime.

Since it was not our intention to generalize to a larger population, we used purposive non-random sampling to recruit specialized informants so we could determine a range of perceived changes and capture the widest array of perspectives (Creswell 2014). Semi-structured interviews were conducted with 29 participants who represented different groups of actors involved in influencing, making decisions about or developing forest policies. We chose participants from several regions of the province who were directly involved or had firsthand experience with the policy regime. All participants, except for one, were Manitoba residents. Approximately onethird of the participants were from urban centres while the remaining two-thirds were from rural Manitoba. Eight of the participants were members of a stakeholder advisory committee working with one of the commercial forestry companies operating in the province. Five of the 29 participants were female.

To protect confidentiality, alphanumeric codes were given to associate each participant with the actor group she or he was from and the codes were used for comparative analysis. The codes have been maintained in the final text to enhance transparency, a tool for ensuring validity in qualitative research (Creswell 2014). Table 1 identifies the various actor groups, the codes used and the number of participants in each group.

Interviews lasted approximately one hour and questions were predetermined and existed as part of an interview guide.
Table 1. Actor groups, group codes, and number of participants in each group

\begin{tabular}{lcc}
\hline Actor group & $\begin{array}{c}\text { Actor } \\
\text { group } \\
\text { code }\end{array}$ & $\begin{array}{c}\text { Number of } \\
\text { participants } \\
\text { interviewed }\end{array}$ \\
\hline $\begin{array}{l}\text { Forest industry } \\
\begin{array}{l}\text { Provincial government } \\
(2 \text { departments, } 4 \text { branches })\end{array}\end{array}$ & IND & 7 \\
$\begin{array}{l}\text { Aboriginal organizations } \\
\text { Academics/educators }\end{array}$ & AO & 5 \\
$\begin{array}{l}\text { Environmental non-government } \\
\text { organizations }\end{array}$ & EDU & 3 \\
Non-government organizations & ENGO & 3 \\
Recreational interest groups & NGO & 3 \\
Federal government & REC & 3 \\
Private land holder & FED & 1 \\
\hline Total & PVT & 1 \\
\hline
\end{tabular}

Interviews and notes were transcribed and analysis was conducted using QSR's NVivo qualitative data analysis software (QSR International Pty Ltd. 2006). Interview answers were coded systematically and iteratively until the final categories contained the participants' perceptions of change and continuity in Manitoba's forest policy regime. There were essentially two main categories, each with several subcategories. One main category identified change in objectives and ideas (Table 4) and the other change in actors and roles (Table 5). Through these categories, drivers of and barriers to change were identified. Interview results are framed by the categories and presented using short, direct quotations from the participants along with tallies of the number of participants who raised an issue grouped to that category. We emphasize predominant viewpoints, but following accepted principles in critical and qualitative research, we also include noteworthy perspectives of smaller groups of participants (Miles et al. 2014).

A qualitative content analysis of key policy-related documents helped verify and supplement the interview data. The document set included constitutional documents, statutes and regulations, non-legally binding policy instruments and provincial government annual reports. The data set included The Forest Act and regulations and annual reports from 1930 to the present. It also included a wide array of documents dated from the 1980s to the present. This period was important because the concept of SFM emerged in Canada and internationally. In the next section, the document analysis is presented first and then the participants' perceptions of policy change are presented, including evolution in the roles and relationships of policy actors.

\section{Results}

\section{Early forest policy eras in Manitoba}

Echoing broader trends in natural resource and environmental policy, the evolution of forest policy in Canada can be characterized as having gone through five major eras: unreg- 
Table 2. Major ideas characterizing forest policy eras from pre-1870 to the present (Howlett and Rayner 1995, 2001; Kimmins 1995; Ross, 1997; Burton et al. 2003; Hessing et al. 2005; Hagerman et al. 2010)

\begin{tabular}{|c|c|c|c|c|}
\hline Pre 1870 & Late $1800 s$ & Early to mid $1900 s$ & Mid 1900s & Late 1900 s to present \\
\hline Unregulated exploitation & $\begin{array}{l}\text { Regulation for } \\
\text { revenue generation }\end{array}$ & Conservation & Forest management & $\begin{array}{l}\text { Sustainable Forest } \\
\text { Management }\end{array}$ \\
\hline $\begin{array}{l}\text { Over exploitation of } \\
\text { natural resources } \\
\text { inconceivable and } \\
\text { extraction activities } \\
\text { unregulated }\end{array}$ & $\begin{array}{l}\text { Potential to overexploit } \\
\text { specific types of timber } \\
\text { acknowledged }\end{array}$ & $\begin{array}{l}\text { Increasingly recognized } \\
\text { potential to overexploit } \\
\text { timber resources }\end{array}$ & $\begin{array}{l}\text { Multiple forest } \\
\text { components and } \\
\text { ecological constraints } \\
\text { valued }\end{array}$ & $\begin{array}{l}\text { Forest values reflect } \\
\text { increasingly complex } \\
\text { blend of economic, } \\
\text { ecological and social } \\
\text { systems }\end{array}$ \\
\hline \multirow[t]{2}{*}{$\begin{array}{l}\text { Natural resources lack } \\
\text { economic value }\end{array}$} & $\begin{array}{l}\text { Government revenue } \\
\text { generated through } \\
\text { regulations for } \\
\text { extracting timber }\end{array}$ & $\begin{array}{l}\text { Regulations established } \\
\text { to secure a future } \\
\text { timber supply - sustained } \\
\text { yield timber harvesting } \\
\text { established }\end{array}$ & $\begin{array}{l}\text { Creation of long-term, } \\
\text { area-based, forest } \\
\text { management licenses }\end{array}$ & $\begin{array}{l}\text { Increased government } \\
\text { involvement in environ- } \\
\text { mental protection and } \\
\text { regulation }\end{array}$ \\
\hline & & $\begin{array}{l}\text { Fire suppression, forestry } \\
\text { inventory and natural } \\
\text { regeneration established to } \\
\text { protect forest resources }\end{array}$ & $\begin{array}{l}\text { Forest regeneration } \\
\text { required for long-term } \\
\text { harvesting licenses and } \\
\text { artificial regeneration } \\
\text { initiated }\end{array}$ & $\begin{array}{l}\text { Maintenance of forest } \\
\text { ecology and social systems } \\
\text { integral to forest } \\
\text { management and } \\
\text { planning }\end{array}$ \\
\hline
\end{tabular}

ulated exploitation, regulation for revenue generation, conservation, forest management, and SFM (Howlett and Rayner 1995, 2001; Kimmins 1995, Ross 1997, Burton et al. 2003, Hessing et al. 2005, Hagerman et al. 2010). The major ideas characterizing the eras are summarized in Table 2 and are discussed briefly below. The five eras frame our presentation of the results of the document analysis as the evolution of Manitoba's forest policy regime approximates, in a general way, the characteristics of these five eras.

Prior to the early 1800 s, the exploitation of natural resources was largely unregulated. In the second era, beginning in the early to mid-1800s in some parts of Canada, governments began to generate revenue from resource extraction activities by charging stumpage fees and ground rents. Fees of this type did not become part of Manitoba's policy regime until The Forest Act was established in the 1930s after the province gained constitutional jurisdiction over its natural resources through The Natural Resources Transfer Act of 1930 (Jackson 1970, Stevenson and Webb 2003, Hogg 2006).

In the third era, conservation (early to mid-1900s), the limits of forest resources were recognized and regulations were developed to control harvesting. As well, forests were secured through regeneration and protection efforts (Ross 1997) such as the implementation of long-term forestry allocations and national parks and forest reserves (Hessing et al. 2005). Additionally, efforts to suppress fires, promote natural regeneration, and conduct forest inventory activities were initiated (Howlett and Rayner 1995). An attempt to balance economic growth and use of forest resources in perpetuity, sustained yield management was a key development in the conservation era (Howlett and Rayner 2001). In Manitoba, the conservation era started with the establishment in 1930 of The Forest Act, and this corresponded with longer term allocations of forest resources based on land area rather than timber volume (Ross 1997). As well, sustained yield management plans were established in the late 1940s in conjunction with forest surveys and identified as part of forest management activities (Somers 1948).
The fourth era, forest management (beginning in the mid-1900s), saw sustained yield become institutionalized through legislated, long-term tenure arrangements (Ross 1997). This era also included important developments in silviculture science, greater recognition of ecological constraints, and higher value placed on the multiple components of forest systems (Burton et al. 2003).

The fifth era, SFM (late 1900s to the present), was described in the introduction. An important milestone in the integration of SFM into Canada's forest policy regime was its adoption in Canada's first national forest strategy in 1992 (Ballhorn 2005). Another was the development by the Canadian Council of Forest Ministers (2003) of six criteria for establishing SFM. The scope of the criteria ranges from maintaining biological and ecological components and functions nationally and globally, to maintaining economic and social benefits for future generations.

Legislative and Policy Change in Manitoba during the SFM Era In Manitoba, SFM was shaped in important ways by seven statutes: 1) The Ecological Reserves Act (1981); 2) The Environment Act (1987); 3) The Endangered Species Act (1990); 4) The Provincial Parks Act (1993); 5) The Sustainable Development Act (1997); 6) The Forest Health and Protection Act (2007); and, 7) The East Side Traditional Lands Planning and Special Protected Areas Act (2009) (Table 3). Through this legislation, environmental and ecological protection was strengthened, and broad-scale planning and consideration for social values was introduced. Additionally, more inclusive participation in forest management and decision-making was introduced, along with government-to-government relationships and engagement with Aboriginal communities on land use planning and resource management.

A similar evolution of ideas was identified in non-statutory forest policy documents and annual reports from Manitoba Conservation's Forestry Branch (Table 3). The scientific principles of sustained yield, introduced in the 1940s during the conservation era, were maintained in policies and reports 
Table 3. Major policy instruments, concepts, principles and objectives that have influenced Manitoba's forest policy regime in the Sustainable Forest Management era

\begin{tabular}{lcccccccc}
\hline & \multicolumn{7}{c}{ Concepts, principles and objectives } \\
\cline { 2 - 8 } Policy instruments & 1980 & 1985 & 1990 & 1995 & 2000 & 2005 & 2010 \\
\hline
\end{tabular}

The Ecological Reserves Act, C.C.S.M. c. E5, 1981

The Environment Act, C.C.S.M. c. E125, 1987

The Endangered Species Act, C.C.S.M. c. E111, 1990

The Provincial Parks Act, C.C.S.M. c.P20, 1993

The Sustainable Development Act, C.C.S.M. c.S270, 1997

The Forest Health and Protection Act, C.C.S.M. c. F151, 2007

The East Side Traditional Lands Planning and Special Protected Areas Act, C.C.S.M. c. E3, 2009
Research, enjoyment and preservation of ecological features

Protection and maintenance of the environment to sustain a high quality of life (social and economic development, recreation and leisure opportunities)

Protect and enhance the survival of endangered and threatened species

Protect (12\%) of natural lands and quality of life

Implement and promote sustainable development in the public sector, industry and society

Protect tree, forest and ecosystem health

Government-to-

government
relationships
Land use and
resource manage-
ment planning
with Aboriginal
communities
Protection from
development and
other activities

Objectives for the 80's (1980)

Sound and responsible management

Optimal economic utilization of forest resources; scientific, administrative, economic and social considerations associated with forests and forestry; integrated resource management

Integrated resource management through increased interaction between the forest and wildlife branches

Sustainable development

Sustainable Forest Management

Ecosystem-based forest management

Manitoba's Forest Plan towards Ecosystem Based Management (1995)

Next Steps: Priorities for Sustaining Manitoba's Forests (2002)

Manitoba Conservation Forestry Branch Annual

Sustained yield

Sustainable development

Integrated resource management
Scientific and traditional knowledge; ecological and socioeconomic values; economic development and co-management opportunities with Aboriginal communities; policy revision
Manitoba Conservation Forestry Branch Annual Reports (1990 - 2010)
Ecosystem-based management into the 1980s. However, new ideas about multiple forest uses and management (e.g., integrated resource management), forest ecosystems and inclusion of Aboriginal communities and traditional knowledge were acknowledged as part of the principles of SFM beginning in the early 1990s.
Additionally, through a public consultation process, the roles that government, industry and the public were to play in achieving SFM were identified and recommendations were compiled into a document entitled What You Told Us Workbook on Forests (Table 3). From there, social objectives of 
SFM, such as respecting traditional ecological knowledge, stewardship and co-management, and economic development opportunities for Aboriginal communities were identified in a subsequent policy document, Next Steps: Priorities for Sustaining Manitoba's Forests (Manitoba Conservation (2002) (Table 3).

Reviewing The Forest Act was identified as an objective in the Next Steps document, and amendments to the Act were made in 2009. An important change was the prohibition of logging in most of Manitoba's provincial parks. A minor revision was that "sustained yield basis" became a guiding principle for harvesting under forest management licenses, replacing "sustained yield capacity" and "sustained yield management". A search of terms in the amended Act did not reveal any of the following terms: sustainable, sustainability, Aboriginal, First Nation, ecosystem, ecology or environment. Finally, a search for social, as in social values or considerations, revealed that section 11 included a statement that timber harvesting rights may be allocated to people or organizations to improve social and economic well-being of an area or community.

\section{Current forest tenure mechanisms}

Before turning to the perceptions of the research participants regarding change and continuity in Manitoba's forest policy regime, we will briefly describe existing forest tenure mechanisms used in the province. This information provides further context for the views held by the various policy actors we interviewed.

The Province of Manitoba allocates harvesting rights to forestry companies through Forest Management Licenses which are long-term arrangements covering a designated area. The licenses cover almost half (12.2 million ha) of Manitoba's total forest and wooded land area and $82 \%$ of the province's Crown timber is harvested by license holders. Harvesting rights are also allocated through volume-based arrangements called Timber Sale Agreements. Holders of these rights harvest approximately $15 \%$ of the province's Crown timber. The remaining 3\% of Crown timber harvested is for firewood, fence posts, and small-scale lumber/sawmill operations, and these rights are allocated through Timber Permits (Manitoba Conservation and Water Stewardship 2014a).

Until recently, there were three Forest Management License holders in Manitoba: Tembec Forest Products Inc., Tolko Industries Ltd., and Louisiana-Pacific Canada Ltd. Tembec closed its newsprint mill in September 2010 and the closure was attributed to a combination of a decline in the newsprint market and the cost structure of the mill (Tembec 2010). Structural and market factors have also recently affected Tolko and Louisiana-Pacific. Tolko Manitoba (2009) identified low housing starts in the US, a high Canadian dollar, and a provincial penalty associated with export quotas and duties as contributing to the company's decision to reduce its operating capacity. Although the Canadian forest sector has partially rebounded from such structural and market challenges, Tembec has not renewed operations in Manitoba and the province's forest sector has not returned to its pre-downturn levels of activity (Manitoba Conservation and Water Stewardship 2014b, Natural Resources Canada 2009; 2014).
In summary, the document review revealed that the evolution of Manitoba's forest policy regime approximated the characteristics of the five main eras in Canadian forest policy (Table 2). In the SFM era there have not been substantial changes to Manitoba's central forestry legislation, The Forest Act, but the province has seen the establishment of important sustainability-related policy instruments (e.g., The Forest Health and Protection Act), concepts (e.g., ecosystem-based management), principles (e.g., valuing traditional knowledge), and objectives (e.g., promote sustainable development) (Table 3).

\section{Perceptions of change and continuity in the forest policy regime: Policy objectives}

The policy objectives discussed by research participants paralleled the changes identified in the document analysis. We asked four specific questions about objectives: "Tell me about the major objectives of Manitoba's forest policies."; "What major steps are being taken to achieve these objectives?"; "Have these objectives changed in the last few decades?"; "In the affirmative, how and when have they changed?"

Participants discussed sustained yield, SFM, increasing economic opportunities, protecting ecosystems, involving the public and improving consultations with First Nation and Aboriginal actors (Table 4). Approximately half the participants $(\mathrm{x}=15)$ indicated that government forest policy remained focused on economic values derived from forestry activities and maintaining a steady flow of fibre (Table 4; objectives 1-4). A similar number $(\mathrm{x}=16)$ identified a shift from sustained yield or sustainable fibre towards SFM (Table 4; objective 5). Many $(\mathrm{x}=18)$ described forest policies as inclusive of multiple objectives and forest values (e.g., aesthetic, recreational, intrinsic and economic) or they recognized a need to balance ecosystem protection with forestry activities (Table 4; objectives 6, 7 and 10). Protected areas were also recognized as a forest management consideration associated with increased and diverse forest interests (IND2).

An increase in public involvement (Table 4; objective 8) (x = 10) through legitimization of new actors (FED1) and a growing interest and demand for transparency and accountability (IND1, NGO1, PROV5) were identified as mechanisms to improve the quality of decisions (PROV1, PROV5) and to foster change (ENGO2). Furthermore, greater consideration for, and actual inclusion and participation of, Aboriginal actors were also recognized (Table 4; objective 10) $(\mathrm{x}=4)$. Two participants indicated that there were efforts focused specifically towards involving First Nations in forest education and employment (IND3) and in decision-making (FED1). However, involvement opportunities available to Aboriginal actors were largely identified as being at the operational level (PROV2, IND4, IND5) rather than in decisionmaking processes. An additional shift associated with Aboriginal actors was awareness of revenue sharing and capacity building as well as increased recognition, awareness and appreciation of traditional ecological knowledge.

\section{Management concepts and operations}

In addition to recognizing longstanding, new and emerging policy objectives, the research participants discussed how forest management concepts had changed and how these changes affected policies and operations. These data were 
Table 4. Forest policy objectives identified by interview participants (represented by alphanumeric codes)

Policy objectives

1. Revenue generation

2. Rural economic development

3. Job creation

4. Sustained yield (including maintaining a perpetual fibre supply)

5. Sustainable Forest Management (including sustainable development, sustainability, and maintaining resources for future generations)

6. Environmentally friendly forestry activities

7. Forest and ecosystem protection

8. Public involvement (including consultation)

9. Aboriginal involvement (including resource sharing, capacity building, and respecting traditional forest uses)

10. Balancing multiple values (e.g., economic, environmental, social, wise use, aesthetic, recreational, and intrinsic)
Interview participants

PROV3, PROV5, IND4, ENGO2

PROV5, ENGO2, ENGO3

IND1, IND5

PROV1, PROV2, PROV3, IND3, IND4, IND7, NGO1, NGO2, REC1, ENGO1

AO1, AO2, NGO3, EDU1, EDU2, EDU3, FED1, PROV1, PROV2, IND2, IND3, IND4, IND5, PROV5, REC1, REC3

AO2, IND1, IND2, IND5

NGO3, PROV1, PROV3, IND2, IND3, IND4, PROV5, ENGO3, ENGO1

AO2, EDU3, FED1, PROV1, PROV3, IND1, IND4, NGO1, PROV5, ENGO2

EDU1, PROV3, IND4, ENGO1

AO2, NGO3, EDU1, EDU2, FED1, PROV2, IND2, IND3, IND4, IND5, NGO1, NGO2, PROV5, REC1, ENGO1, ENGO3 elicited in response to the questions about objectives noted above, and also in answers to four follow- up questions: "Have you observed any other significant changes in the forest sector?"; "Were changes in forest policies incremental or were they abrupt?"; "What provoked these changes?"; "Are Manitoba's forest policies flexible with respect to changing values/changing environment?".

One participant identified Next Steps: Priorities for Sustaining Manitoba's Forests (2002) as an important policy document that recognized new ideas (EDU3) such as the principles of SFM. Others specifically referred to The Environment Act (NGO1) and its environmental assessment process (EDU1) as an important mechanism for collaboration and public involvement in forestry licensing. In contrast, nearly half the participants $(\mathrm{x}=13)$ viewed the primary forest legislation, The Forest Act, as being static or outdated. Other perceptions related to The Forest Act were that it was in the process of being updated, or updates were unnecessary as the Act was "flexible enough that new things can be accommodated" (NGO2).

At the operational level, participants' perceptions of change were varied. Some participants identified positive changes in operations (EDU3, ENGO2 and ENGO1), while others thought that forest management practices had not improved (NGO1). Several participants suggested that changes in policy objectives had not resulted in operational change, e.g., lack of recognition for protected areas within forest management licenses (ENGO1), increased annual harvesting levels (EDU3), and greater emphasis on longterm employment rather than forest health and protection (ENGO2). One industry participant thought that government decisions lagged behind practice, indicating that policy was often based on activities already occurring in the industry. One ENGO participant (ENGO2) indicated changes in operations had occurred because the forest industry was now required to protect or limit damage to ecological components, such as wildlife habitat, water and soil. However, an industry participant indicated that operating in a "sustainable manner" was good for business: "It's not just about the environment" (IND5).

\section{Policy actors, their roles, and their relationships}

The participants were asked six general questions about the roles, importance and evolution of policy actors in Manitoba's regime. In some cases, we supplemented the answers with specific inquiries about tenure arrangements and the roles and importance of Aboriginal peoples, regional and local governments, non-government organizations, and the federal government. Table 5 summarizes the responses. In discussing actors and roles, the participants also shared their views on relationships among the actors. Manitoba's forest policy community was described as small and integrated (FED1) and the overall relations among actor groups were described as cordial and lacking high profile land use disputes. According to one participant (FED1), the industry players were too few, the timber and ecology were not highly valued, there was ample wild land and protected areas, and thus conflict was relatively minimal. A corresponding sentiment was that there were more pressing issues than forestry, namely those related to water, oil, mining and climate change (EDU1). One industry participant (IND3) indicated that the relationships among actors were better than they were a decade ago because trust was being built and actors were sharing information with one another. However, another participant (EDU2) indicated that conflicts did exist, particularly with respect to large forestry allocations and co-management and planning with First Nations.

The provincial government was described (NGO3, REC2) as the main policy actor even though other actors and inter- 
Table 5. Research participants' (represented by alphanumeric codes) perceptions of the actors in Manitoba's forest policy regime and the roles the actors play in the regime

\begin{tabular}{|c|c|}
\hline Policy actor & Roles \\
\hline $\begin{array}{l}\text { Provincial government } \\
\text { (central forestry branch) }\end{array}$ & $\begin{array}{l}\text { 1. Develop policies; be the authoritative decision-maker (FED1, IND1, REC1, REC2, ENGO1) } \\
\text { 2. Manage Crown resources on behalf of the public (EDU3) } \\
\text { 3. Allocate forest resources (EDU3, NGO1) } \\
\text { 4. Build relationships with rural and Aboriginal communities (ENGO2) }\end{array}$ \\
\hline $\begin{array}{l}\text { Provincial government } \\
\text { (regional forestry branch) }\end{array}$ & $\begin{array}{l}\text { 5. Implement and enforce policies (EDU1, IND2, IND4, IND5, IND6, NGO1, NGO2, PROV5, REC1, } \\
\text { REC2, REC3, ENGO2, ENGO1) }\end{array}$ \\
\hline Forest industry & $\begin{array}{l}\text { 6. Generate revenue (EDU3, IND4, IND5, IND7, ENGO1) } \\
\text { 7. Support and participate in government policy making (IND1, IND3, IND4, IND5) } \\
\text { 8. Drive government actions and decisions (PVT1) } \\
\text { 9. Challenge government policies (ENGO1) }\end{array}$ \\
\hline Aboriginal people & $\begin{array}{l}\text { 10. Work in forestry positions as independent loggers and contractors } \\
\text { (AO, EDU2, IND5, IND7, ENGO2, ENGO1) } \\
\text { 11. Participate in forestry and land use planning and consultations } \\
\text { (AO2, AO3, EDU1, PROV5, REC2, ENGO2) } \\
\text { 12. Operate resource management boards (EDU2) } \\
\text { 13. Initiate government-to-government negotiations (AO1, EDU2, PROV2, IND1, IND5, IND7, ENGO1) } \\
\text { 14. Establish Duty to Consult protocol (ENGO1) }\end{array}$ \\
\hline Federal government & $\begin{array}{l}\text { 15. Set high level policies and promote national forest initiatives (EDU1, IND4, IND7, NGO1, ENGO2) } \\
\text { 15. Provide funding (partner with province; fund the Manitoba Model Forest) } \\
\text { (EDU3, PROV2, IND3, ENGO3) } \\
\text { 17. Promote and represent Canadas forest sector internationally (IND3, ENGO3) } \\
\text { 18. Legislative authority (e.g., Indian Act, migratory birds, fisheries and oceans) (PROV3, IND3, NGO1) }\end{array}$ \\
\hline
\end{tabular}

Stakeholder advisory committees

Environmental and other nongovernment organizations

Rural municipalities and regional conservation districts

Manitoba Agriculture and small-scale forestry businesses
19. Represent public interests through two way flow of communication with industry (AO3, NGO3, EDU1, IND2, REC1, REC2, REC3, ENGO1)

20. Develop and conduct research with other actor groups (IND3, NGO2)

21. Persuade public and pressure governments to further environmental protection and preservation agendas (EDU1, NGO1)

22. Interact with other actor groups over local issues (NGO3, EDU1, EDU2, FED1, PROV2, PROV3, IND1, IND2, IND3, I216, REC1, IND7, PVT1, ENGO1)

23. Promote sustainable forestry on private land (EDU3, IND7, PROV5, ENGO2) ests were recognized as being involved or having an influence (EDU3, FED1, IND1, NGO1). The role of the provincial government was described as managing Crown resources on behalf of the public (EDU3), being the authoritative decisionmaker (Table 5; Role 1) $(\mathrm{x}=5)$, and developing, implementing and enforcing regulations and policies (Role 5) $(\mathrm{x}=13)$. An ENGO participant (ENGO2) described the role of the provincial government as a facilitator of industrial logging rather than forest preservation. Participants recognized the basis of the relationship between the provincial government and the forest industry as being long-term forestry allocations. Forest management licenses were viewed as the main form of tenure because they underpinned the majority of forested land and forestry activities in Manitoba $(\mathrm{x}=11)$.

In contrast to the view that the provincial government was the main policy actor, the forestry industry (EDU3, IND7) and First Nations (IND7) were described as being lead actors. The forest industry was viewed as having an influence and being involved in policy development and review. Building relationships with rural and Aboriginal communities was identified as a role of the provincial government (Role 4) (ENGO2).
The relationships among the provincial government, the forest industry and Aboriginal actors were associated with constitutionally recognized Aboriginal rights. Aboriginal actors were viewed as being involved in forestry and land use planning consultations (Role 11) $(\mathrm{x}=6)$, and at the political level through government-to-government relations (Role 13) $(x=7)$. Conflict between the provincial government and Aboriginal people was identified and associated with large forestry allocations constraining co-management opportunities (Role 12) (EDU2). A vital and emerging avenue identified for increased involvement of Aboriginal people dealt with the duty to consult associated with Supreme Court of Canada rulings on Section 35 of the Constitution Act, 1982 (Role14) (ENGO1). Additionally, participants described Aboriginal actors being involved at the operational level through employment opportunities, and as independent loggers and contractors (Role 10) $(\mathrm{x}=6)$.

In contrast to the lead role of the provincial government, the role of the federal government was described as setting high-level policy objectives and developing the National Forestry Strategy (Role 15) $(\mathrm{x}=5)$. The federal government was also described as representing and promoting the Cana- 
dian forest industry internationally (Role 17) $(x=2)$. Dissemination of national policies to the provincial level was both anticipated and doubted (NGO1). Even though opportunities for the provincial government to provide input to nationallevel policies were identified (PROV1, IND7), the influence and role of the federal government in Manitoba were viewed as limited because of the provincial government's constitutional authority to control and manage natural resources $(\mathrm{x}=$ 7). Furthermore, this decentralized jurisdiction over natural resources was identified as an inhibitor of developing national strategies (FED1, NGO1, PROV5). Participants indicated that the federal government was involved in Manitoba's forest policy regime because it had constitutional authority regarding Aboriginal people, as well as legislative authority over fisheries and oceans and migratory birds. They were also acknowledged as a funding agency or partner with the province and for providing monetary support for the Manitoba Model Forest (Role 18) $(\mathrm{x}=3)$.

The role of ENGOs was perceived as persuading the public and pressuring government for policy change about environmental protection and ecosystem preservation (Role 21) $(x=2)$. In contrast, other non-government organizations were described more as research partners (Role 20) $(x=2)$. One organization in particular, the Manitoba Model Forest, was perceived as having an increasingly important role in the policy regime because it was viewed as providing an opportunity for multiple actors to work together on social issues and research related to forestry and to build trust among actors. Environmental groups were implicated in the regime because the environmental movement, campaigns and lobbying were viewed as triggers that altered the way government and industry viewed forestry.

Participants perceived the members of forestry companies' stakeholder advisory committees as representing various values associated with public interest groups. These members were perceived as providing input and information, often in the form of concerns or issues, from their respective associations to the forestry company or vice versa (Role 19) $(\mathrm{x}=7)$. The purposes for providing information varied from helping the forestry company avoid controversy over environmental issues (REC1) to benefiting forest policies by contributing multiple values and opinions (NGO3). One ENGO representative described the role of advisory committee members as challenging the status quo.

Participants perceived rural municipalities and regional conservation districts as having a role in interacting with other actor groups over local issues in stakeholder advisory committees and other public involvement opportunities (Role 22) $(\mathrm{x}=14)$. Participants indicated that rural municipalities needed to have input (PROV2) and be informed (IND3). Municipalities were also viewed as interacting with industry over operational issues and local economic benefits of forestry activities, such as employment opportunities. They were also perceived as becoming increasingly involved, largely through afforestation projects, private land management and woodlots (IND7) due to a perceived demand for fibre from private land (IND7, PVT1).

Although participants described forestry and agriculture as independent policy regimes (EDU3, IND7, PVT1, PROV5), the provincial ministry of agriculture offered extension services regarding private land forestry and woodlot management. Moreover, some participants $(\mathrm{x}=4)$ saw a role for the ministry, in conjunction with small-scale forestry businesses, to promote sustainable forestry on private land (Role 23). However, the independence of the forestry regime from the agricultural regime was viewed as leading to challenges, such as incorrect land classification (EDU1, PROV5), inappropriate use of land, and a lack of foresight in determining the most appropriate use of land (PVT1, PROV5). One participant (PVT1) perceived Manitoba Conservation's Forestry Branch as having an aversion to small-scale forestry despite the fact that private forestry made an important contribution to the forest sector because of the amount of forest products produced. The increased demand for fibre from private land was identified as an issue because forestry on private land is unregulated. However, participants also indicated that efforts have been made to educate private landholders about the best use of their forested land, i.e., managing woodlots sustainably. Participants indicated that public concern, woodlot programs, and government and industry interaction encouraged these education initiatives (EDU3, IND7, PROV5, ENGO2).

In summary, the interview results paralleled key observations and trends identified in the document review, but added considerable depth and nuance. Despite the lack of changes to The Forest Act, the policy regime in the SFM era was sufficiently flexible to adopt aspects of SFM, such as forest and ecosystem protection and balancing a plurality of forest values. At the same time, according to ten participants, maintaining a sustained yield or perpetual fibre supply was still a primary forest policy objective (Table 4). The provincial government was perceived as the lead policy actor, with industry and Aboriginal people as other important players. Rural municipalities and regional conservation districts were identified as minor actors with potential to play bigger roles when it came to local issues. Diverse roles were identified for the provincial and federal governments, consistent with their constitutional authority. Along with generating revenue, industry was seen as driving and supporting public policy making. Along with working in forestry operations, opportunities were seen for Aboriginal people to participate in government-to-government negotiations, revenue sharing, and co-management. Generally, the relationships among the policy actors were viewed as cordial and lacking significant conflict.

\section{Discussion}

In many respects, Manitoba's forest regime is a classic example of a closed policy network (Howlett and Rayner 1995). Consistent with Bullock's (2013) results, we found a stable and dominant relationship between the provincial government and the forest industry along with a small and exclusive core of central policy actors. This state of affairs is likely maintained by the relatively small size of the industry in Manitoba and the institutionalized forest tenure established in The Forest Act. Despite this exclusivity, some changes in Manitoba's forest policy regime have occurred since the emergence of the concept of SFM over two decades ago. Policy regime changes can occur-even in a relatively closed network-if the central actors are receptive to learning from other jurisdictions and to adopting new policy directions (Howlett and Ramesh 2002). 
The analysis of Manitoba's regime suggests, therefore, that the provincial government and the forest industry have been open to learning from the experiences in other parts of Canada. That being said, the results also reveal that although new ideas associated with SFM have entered the Manitoba regime, the changes have not been ubiquitous in both discretionary policy instruments and in legislation, which has reduced the degree to which new ideas and objectives have become entrenched. It is significant that The Forest Act has undergone little change since the 1980s in comparison to other types of forest policies and environmental legislation in Manitoba and in comparison to forest legislation in other Canadian provinces. For example, since the late 1980s to mid-1990s Québec, Ontario, Saskatchewan and British Columbia have legislated changes that acknowledge principles of SFM. These changes include balancing economic, ecological and social values, increased public involvement opportunities, and partnerships with Aboriginal communities (Ross 1997). More recently, paralleling in several important respects policy reform in Ontario (Chiasson et al. 2013), Québec adopted new legislation, The Sustainable Forest Development Act, which came into force in April 2013. This statute not only redefined the role of the natural resources ministry in forest management but also emphasized forest ecosystem management. The new regime also involves a major redefinition of the principal actors of forest governance, and emphasizes greater government accountability with regard to the management and regionalization of decision-making (Amedzro St-Hilaire and Chiasson 2012).

In addition to learning, changes in policy regimes involving closed networks can be explained by changes in the interests of the central actors (Howlett and Ramesh 2002). If a central actor becomes receptive to the interests of a party outside of the core network, new ideas and objectives could be adopted in the regime. However, given that policy-making continues to be led by the central actors, such shifts in interests tend to represent incremental rather than deep-seated or transformative policy change (Howlett and Ramesh 2002). It is no surprise then that change in the Manitoba regime has tended to be relatively slow and incremental. The development of new policy objectives aimed at increased involvement and partnerships with Aboriginal people is a case in point.

Greater involvement of Aboriginal people is being sought, but many of the opportunities have been at operational rather than strategic and normative levels of governance. More ambitious forms of collaboration, such as shared decisionmaking and Aboriginal-held forest tenures (Wyatt et al. 2013) have not been widely adopted in Manitoba (Fortier et al. 2013), likely hindered by the closed nature of the policy network. The types of changes witnessed in Manitoba are consistent with experiences elsewhere in Canada, with opportunities for meaningful governance participation lagging behind the development of immediate economic opportunities in Aboriginal communities (Wyatt 2008).

In Manitoba, these changes have been mainly driven by constitutionally-recognized Aboriginal rights, governmentto-government relations, and court-defined duty to consult processes. They have also been shaped by the increased role of Aboriginal people on the periphery of the regime, which provides a source of political pressure and an impetus for actors at the core of the regime to further the interests of Abo- riginal actors. Furthermore, recent electoral successes of the Manitoba New Democratic Party (NDP) can be attributed, in part, to its support from Aboriginal and northern communities. Nearly six-in-ten Aboriginal Manitobans typically back the provincial NDP (Probe Research 2010). This support provides further receptivity of Aboriginal interests in public policy. However, for more transformative change to occur, the centre of the forest policy network will need to be opened to Aboriginal policy actors. At present, decision-making opportunities for Aboriginal Manitobans are relatively rare (Fortier et al. 2013); there is a gap between provincial authority over forest resources and federal authority regarding Aboriginal people, and Aboriginal rights are not fully defined (Curran and M'Gonigle 1999, Stevenson and Webb 2003).

Facilitating transformative change with respect to the role of Aboriginal people will also involve overcoming challenges in aligning traditional ecological knowledge with the sciencebased knowledge systems that currently dominate forest management. These two knowledge systems are based on fundamentally different epistemological beliefs and linguistic systems (Berkes 2012). These differences hinder the inclusion of traditional ecological knowledge in forest management and policy even though it is a recognized component of new relationships with Aboriginal actors (Sherry et al. 2005, O'Flaherty et al. 2008). Additionally, colonization has fostered mutual mistrust between Aboriginal and non-aboriginal people, and an emphasis on professionalism provides validation for resource management based on scientific knowledge systems while discounting other systems (Hawley et al. 2004).

Another type of change identified in the Manitoba regime was the use of new forms of policy instruments such as stakeholder advisory committees and non-regulatory guidance documents like Next Steps. This type of change is often associated with efforts to continue with existing policy ideas when faced with emerging new policy actors. New actors can infiltrate a policy network as a result of systemic exogenous forces (Howlett and Ramesh 2002), such as environmental or ecocertification campaigns, international movements advancing Indigenous rights, and constitutional amendments recognizing Aboriginal rights. And in fact, all of these forces were identified as catalysts of change in Manitoba's regime. New actors can also penetrate a network through policy subsystem spillovers (Howlett and Ramesh 2002), which occurred in Manitoba when changes were brought about by non-forest legislation (e.g., The Endangered Species Act, The Environment $A c t$ ) and environmental hearings. As noted earlier, new actors identified in Manitoba's regime were Aboriginal actors, the federal government, environmental and other non-government organizations, stakeholder advisory committees, rural municipalities, regional conservation districts, Manitoba Agriculture and private woodlot operations.

Using new forms of policy instruments can have the effect of continuing existing policy ideas through path dependence. Through this process, past decisions dictate or constrain current options, and existing policy regimes, therefore, remain stable (Howlett and Ramesh 2002). In our view, Manitoba's Next Steps document is an example of path dependence. Although the arrival of new actors led to the creation of a new policy document, the influence of pre-existing institutions resulted in the use of a policy instrument without the force of law, which meant it did not conflict with or over-ride The For- 
est Act. Stakeholder advisory committees are another example. Industry was required by government to establish these committees but the requirements were set out in forest management license agreements (McGurk et al. 2006), thereby legitimizing old policy ideas manifest in institutionalized tenure arrangements. The committees also show how change can tend toward incrementalism within the scope of existing institutionalized policy mechanisms. The advisory committees have improved public involvement and have included First Nations representatives, but they fall short of transformative change such as many forms of Aboriginal forestry (Wyatt et al. 2013) or community forestry (Teitelbaum and Bullock 2012). Neither have they enabled progress on protecting land nor in settling land claims in traditional areas, particularly within forest management license areas. Moreover, advisory committees can be viewed as an "affirmative action" policy that co-opts dissenting groups into the very forest policy regime that marginalized them in the first place (Thorpe and Sandberg 2007).

Although the use of new forms of policy instruments is associated with preserving existing ideas when faced with new policy actors, the Next Steps document did include some new ideas and objectives. The new forest policy actors in Manitoba, emerging from systemic perturbations and subsystem spillovers, did therefore manage to overcome path dependence to some extent. The fact that Next Steps was not legally enforceable indicates that they infiltrated the policy network at a decision point where normative goals were set. However, the fact that The Forest Act was not changed shows that neither new ideas nor new actors penetrated the network at a point where law reform decisions were made. Until new actors and ideas are involved in legislative development, the existing central actors will continue to promote their interests when moving from normative to strategic and operational policy decisions.

\section{Conclusion}

Almost two decades ago Howlett and Rayner (1995) argued that, although the interests of new actors have been recognized in Canada's forest policy regime, they have yet to become institutionalized in forest policy-making. To a certain extent, the same is still true for Manitoba. New ideas and objectives associated with SFM have been introduced in the regime and new actors are playing increasingly important roles. However, long-term forest tenure arrangements and enduring relationships between the provincial government and the forest industry have created a relatively closed policy network. An outcome is that sustained yield of timber and fibre remains institutionally entrenched (in forest management licenses). For SFM to take a deeper hold in Manitoba in both policy and in management practices, more transformative change needs to occur. A broader array of interests needs a voice at the centre of the network, and The Forest Act requires amendment to entrench SFM objectives and principles.

A starting point would be a thorough, inclusive and wellresourced consultation on reform of the Act. Manitoba is not a stranger to such law reform processes, e.g., the ongoing multi-year consultations on The Environment Act, and so one could reasonably expect active engagement from stakeholders, rights holders, interested publics, and forest managers and scientists. That being said, public consultations on forestry reform would be highly challenging. The provincial government would need to have industry and Aboriginal people on side, would need to avoid consultation fatigue among the interested actors, would need determined political will, and most importantly, would need a clear commitment to seeing SFM adopted in Manitoba. These are formidable hurdles no doubt, but in our view they are not insurmountable given the reforms we have seen elsewhere in Canada.

\section{Acknowledgements}

We wish to thank the research participants, who gave generously of their time in sharing with us their views and experiences. We also gratefully acknowledge funding support from the Social Sciences and Humanities Research Council of Canada and the Canada Research Chair in Dendrochronology at The University of Winnipeg. We also thankt wo anonymous reviewers and Dr. Ryan Bullock of the Department of Environmental Studies and Sciences at The University of Winnipeg for providing constructive comments on an earlier draft of this manuscript.

\section{References}

Adamowicz, W.L. and P.J. Burton. 2003. Sustainability and sustainable forest management. In P.J. Burton, C. Messier, D.W. Smith and W.L. Adamowicz (eds.). Towards sustainable management of the boreal forest. pp. 41-64. NRC Research Press, Ottawa.

Amedzro St-Hilaire W.G. and G. Chiasson. 2012. État et gouvernance des forêts au Québec. Revue française d'administration publique. 2(142): 517-532. doi: 10.3917/rfap.142.0517.

Ballhorn, R. 2005. The role of government and policy in sustainable development. McGill Int. J. Sustainable Dev. Law and Policy 1(1): 19-27.

Berkes, F. 2012. Sacred ecology: traditional ecological knowledge and resource management. 3rd ed. Routledge, New York.

Bullock, R. 2013. Mill town identity crisis: reframing the culture of forest resource dependence in single industry towns. In J. Parkins and M. Reed (eds.). Social transformation in rural Canada: new insights into community, cultures and collective action. pp. 269-290. University of British Columbia Press, Vancouver.

Bullock, F., and K. Hanna 2012. Community forestry: local values, conflict and forest governance. Cambridge University Press, Cambridge.

Burton, P.J., C. Messier, G.F. Weetman, E.E. Prepas, W.L. Adamowicz, and R. Tittler 2003. The current state of boreal forestry and the drive for change. In P.J. Burton, C. Messier, D.W. Smith and W.L. Adamowicz (eds.). Towards sustainable management of the boreal forest. pp. 1-40. NRC Research Press, Ottawa.

Canadian Council of Forest Ministers. 2003. Defining sustainable forest management in Canada - criteria and indicators 2003 [online]. Available from http://www.ccfm.org/pdf/CI_Booklet_ e.pdf [accessed 17 November 2014].

Chiasson, G., É. Leclerc and C. Gonzalez. 2013. Parallel policies: convergence and divergence in forestry management and governance in Ontario and Québec. In L. Côté, J-F. Savard and A. Brassard (eds.). Québec / Ontario relations: A shared destiny? pp. 213-227. Les Presses de l'Université du Québec, Québec, QC.

Creswell, J. 2014. Research design: qualitative, quantitative, and mixed methods approaches. 4th ed. SAGE Publications, Los Angeles. Curran, D. and M. M'Gonigle. 1999. Aboriginal forestry: community management as opportunity and imperative. Osgoode Hall Law Journal 37(4): 711-774. http://digitalcommons.osgoode.yorku.ca/ ohlj/vol37/iss $4 / 1$

Dryzek, J.S. 2002. Deliberative democracy and beyond: liberals, critics, contestations. Oxford University Press, Oxford. 
Fortier, J.F., S. Wyatt, D.C. Natcher, M.A. Smith and M. Hebert. 2013. An inventory of collaborative arrangements between Aboriginal peoples and the Canadian forest sector: Linking policies to diversification in forms of engagement. J. Environ. Manage. 119: 47-55. doi.org/10.1016/j.jenvman.2013.01.005

Hamersley Chambers, F. and T. Beckley. 2003. Public involvement in sustainable boreal forest management. In P.J. Burton, C. Messier, D.W. Smith and W.L. Adamowicz (eds.). Towards sustainable management of the boreal forest. pp. 113-154. NRC Research Press, Ottawa.

Hagerman, S.M., H. Dowlatadbadi and T. Satterfield. 2010. Synthesis observations on drivers and dynamics of environmental policy change: insights from 150 years of forest management in British Columbia. Ecol. Soc. 5(1): 2. Available from

http://www.ecologyandsociety.org/vol15/iss1/art2/ [accessed 17 November 2014].

Hawley, A.W.L., E.E. Sherry and C.J. Johnson. 2004. A biologist's perspective on amalgamating traditional environmental knowledge and resource management. J. Ecosystems and Manage. 5(1): 36-50. Available from http://www.jem.forrex.org/index.php/jem/article/ view/282/201 [accessed 17 November 2014].

Hessing, M., M. Howlett and T. Summerville. 2005. Canadian natural resource and environmental policy. UBC Press, Vancouver.

Hogg, P.W. 2006. Constitutional law of Canada student edition 2006. Thomson and Carswell, Scarborough, ON.

Howlett, M. 2001. Introduction: policy regimes and policy changes in the Canadian forest sector. In M. Howlett (ed.). Canadian forest policy: adapting to change. pp. 3-20. University of Toronto Press, Toronto.

Howlett, M. and M. Ramesh. 2002. The policy effects of internationalization: a subsystem adjustment analysis of policy change. J. Comp. Policy Analysis: Research and Practice 4(1): 31-50. doi: 10.1023/A:1014971422239.

Howlett, M. and J. Rayner. 1995. Do ideas matter? Policy network configurations and resistance to policy change in the Canadian forest sector. Can. Public Administration 38(3): 382-410. doi: 10.1111/j.1754-7121.1995.tb01055.x.

Howlett, M. and J. Rayner. 2001. The business and government nexus: principal elements and dynamics of the Canadian forest policy regime. In M. Howlett (ed.). Canadian forest policy adapting to change. pp. 23-64. University of Toronto Press, Toronto.

Howlett, M. and J. Rayner. 2006. Globalization and governance capacity: explaining divergence in national forest programs as instances of "next generation" regulation in Canada and Europe. Governance: An International Journal of Policy, Administration, and Institutions. 19(2): 251-275. doi: 10.1111/j.1468-0491.2006.00314.x. Jackson, J.A. 1970. The centennial history of Manitoba. The Canadian Publishers, Toronto.

Kimmins, H.P. 1995. Sustainable development in Canadian forestry in the face of changing paradigms. For. Chron. 71(1): 33-40.

Manitoba Aboriginal and Northern Affairs. 2012. Aboriginal People in Manitoba 2012 [online]. http://www.gov.mb.ca/ana/pdf/ AbPeopleMBweb.pdf [accessed 17 November 2014].

Manitoba Conservation. 2001. Five-year report on the status of forestry 1996-2001. Manitoba Conservation Forestry Branch, Winnipeg, MB.

Manitoba Conservation. 2002. Next Steps: Priorities for sustaining Manitoba's forests. Available from http://www.gov.mb.ca/conservation/forestry/pdf/mb-forests/priorities.pdf [accessed 04 December 2014]

Manitoba Conservation. 2006. Five-year report on the status of forestry April 2001-March 2006. Manitoba Conservation Forestry Branch, Winnipeg, MB.

Manitoba Conservation and Water Stewardship. 2013a. Aboriginal relations branch - goals, objectives and initiatives [online]. Available from http://www.gov.mb.ca/conservation/arb/goals/index.html [accessed 17 November 2014].
Manitoba Conservation and Water Stewardship. 2013b. Wabanong Nakaygum Okimawin (WNO) [online]. http:// www.gov.mb.ca/conservation/wno/ [accessed 17 November 2014]. Manitoba Conservation and Water Stewardship. 2014a. Forested crown land tenure [online]. Available from http://www.gov.mb.ca/ conservation/forestry/manage/tenure.html [accessed 04 December 2014]

Manitoba Conservation and Water Stewardship. 2014b. Manitoba's forest industry [online]. Available from http://www.gov. $\mathrm{mb} . \mathrm{ca} /$ conservation/forestry/industry/index.html?print [accessed 19 November 2014].

Manitoba Jobs and the Economy. 2014. Manitoba regions [online]. http://gov.mb.ca/tce/lmi/trends/regions/index.html [accessed 17 November 2014].

McGurk, B., A.J. Sinclair and A.P. Diduck. 2006. An assessment of forest management stakeholder advisory committees: case studies from Manitoba, Canada. Society \& Natural Resources: An International Journal 19(9): 809-826. doi: http://dx.doi.org/10.1080/ 08941920600835569 .

Miles, M.B., A.M. Huberman and J. Saldana. 2014. Qualitative data analysis: a methods sourcebook. SAGE Publications, Los Angeles.

Natural Resources Canada. 2009. The state of Canada's forests: annual report 2009. Natural Resources Canada, Ottawa, CAN. [online]. Available from http://cfs.nrcan.gc.ca/pubwarehouse/pdfs/ 30071.pdf [accessed 19 November 2014].

Natural Resources Canada. 2013a. Canada's forests- statistical data [online]. Available from http://cfs.nrcan.gc.ca/statsprofile/ overview/mb [accessed 18 November 2014].

Natural Resources Canada. 2013b. The state of Canada's forests: annual report 2013. Natural Resources Canada, Ottawa, CAN. [online]. Available from http://cfs.nrcan.gc.ca/pubwarehouse/ pdfs/35191.pdf [accessed 18 November 2014].

Natural Resources Canada. 2014. The state of Canada's forests: annual report 2014. Natural Resources Canada, Ottawa, CAN. [online]. Available from http://cfs.nrcan.gc.ca/pubwarehouse/ pdfs/35713.pdf [accessed 19 November 2014].

O'Flaherty, R.M., I.J. Davidson-Hunt and M. Manseau. 2008. Indigenous knowledge and values in planning for sustainable forestry: Pikangikum First Nation and the Whitefeather Forest Initiative. Ecology and Society 13(1): 6. Available from http://www. ecologyandsociety.org/vol13/iss1/art6/ [accessed 17 November 2014].

Probe Research. 2010. Aboriginal voter intentions, March 2010 [online]. Available from http://probe-research.com/documents/ 100329\%20Aboriginal\%20Voter\%20Intentions.pdf [accessed 17 November 2014]

QSR International Pty Ltd. 2006. NVivo qualitative data analysis software, Version 7.

Ross, M.M. 1997. A history of forest legislation in Canada 1867-1996 CIRL occasional paper \#2. Canadian Institute of Resources Law, Faculty of Law, The University of Calgary, Calgary, AB. Available from http://dspace.ucalgary.ca/bitstream/1880/47210/ 1/OP02History.pdf [accessed 23 December 2013].

Sherry, E., R. Halseth, G. Fondahl, M. Karjala and B. Leon. 2005. Local-level criteria and indicators: An Aboriginal perspective on sustainable forest management. Forestry 78 (5): 513-539. doi: 10.1093/forestry/cpi048.

Somers, J.G. 1948. Annual report 1948 Forestry Branch. Manitoba Department of Mines and Natural Resources, Winnipeg, MB.

Sneddon, C., R.B. Howarth and R.B. Norgaard. 2006. Sustainable development in a post-Brundtland world. Ecol. Econ. 57(2): 253-268. doi.org/10.1016/j.ecolecon.2005.04.013.

Stevenson, M.G. and J. Webb. 2003. Just another stakeholder? First Nations and sustainable forest management in Canada's boreal forest. In P.J. Burton, C. Messier, D.W. Smith and W.L. Adamowicz.(eds.). Towards sustainable management of the boreal forest, pp. 65-112. NRC Research Press, Ottawa. 
Teitelbaum, S. and R. Bullock. 2012. Are community forestry principles at work in Ontario's county, municipal, and conservation authority forests? For. Chron. 88 (6): 697-707. doi: 10.5558/tfc2012-136.

Tembec. 2010. Tembec shuts down permanently its Pine Falls newsprint mill [online]. Available from http://tembec.com/ en/Media/Press-Releases/tembec-shuts-down-permanently-itspine-falls-newsprint-mill [accessed 17 November 2014].

Thorp, J. and L.A. Sandberg. 2007. Knotty tales: Canadian staples and post-staples forest policy narratives in an era of transition from extractive to 'attractive' industries. Canadian Political Science Review 1(1): 57-72. Available from http://ojs.unbc.ca/index. $\mathrm{php} / \mathrm{cpsr} /$ article/view/16 [accessed 17 November 2014].

Tolko Manitoba. 2009. Summary of meeting-The Pas-Proposed Tolko annual operating plan 2010-2011 [online]. Available from http://www.tolkomanitoba.com/AOP.htm [accessed 17 November 2014].

United Nations. 1987. Report of the World Commission on Environment and Development: Our Common Future. Oxford University Press, London.
United Nations. 1992. Report of the United Nations Conference on Environment and Development. Annex 3: Non-Legally Binding Authoritative Statement of Principles for a Global Consensus on the Management, Conservation and Sustainable Development of All Types of Forests [online]. Available from http://www.un.org/documents/ga/conf151/aconf15126-3annex3.htm [accessed 18 November 2014].

Wellstead, A.M., R.C. Stedman and J.R. Parkins. 2002. Understanding the concept of representation within the context of local forest management decision making. Forest Policy and Economics 5(1): 1-11. doi.org/10.1016/S1389-9341(02)00031-X.

Wyatt, S. 2008. First Nations, forest lands, and "Aboriginal forestry" in Canada: from explosion to comanagement and beyond. Can. J. For. Res. 38(2): 171-180. doi: 10.1139/X07-214.

Wyatt, S., J.-F. Fortier, D.C. Natcher, M.A. Smith and M. Hébert, 2013. Collaboration between Aboriginal peoples and the Canadian forest sector: a typology of arrangements for establishing control and determining benefits of forestlands. J. Environ. Manage. 115: 21-31. doi: 10.1016/j.jenvman.2012.10.038. 